\title{
Assessing the potential of coniferous greenery from logging residues in Latvia using a system dynamics model
}

\author{
Indra Muizniece, Elina Dace, Dagnija Blumberga \\ Institute of Energy Systems and Environment, Riga Technical University. \\ Address: Azenes street 12/1, Riga, LV 1048, Latvia
}

\begin{abstract}
Latvia is the fourth most forested country in Europe. $52 \%$ of the country's area is covered by forest lands. Approximately $41 \%$ of the forests are composed of conifers that are the most harvested among the tree species in Latvia. Therefore, as a result of logging, large amount of coniferous residues are created and abandoned in forests. There are several alternatives for sustainable use of coniferous residues. Still, the exact quantity of the resource is not known. Thus, it is not clear, whether its amount is sufficient for products' manufacturing. The aim of the study is to assess the potential of the coniferous greenery from logging residues' extraction in Latvia. A system dynamic's model that allows simulation of complex forestry processes depending on various endogenous and exogenous factors has been built for this purpose.
\end{abstract}

Keywords: biomass, coniferous, greenery, logging residue, system dynamics.

\section{INTRODUCTION}

In the European Union development strategy "Europe 2020" [1] has been mentioned that bioeconomy is as a key element to the smart and green development in Europe. In the 2012 European Commissions confirmed strategy "Innovating for Sustainable Growth: A bioeconomy for Europe" [2], that includes sustainable production from renewable resource, which is based on closed cycle (circular) economy. In this kind of cycle wastes from one process are resources for another. If we would implement principles of bioeconomy, the economic situation in Latvia could evolve based on the strongest sectors in country - agriculture and forestry.

Unfortunately, utilization of forest resources in Latvia cannot be called sustainable. It is particularly distinct for forest logging residues that are usually left to rot in felled forests in huge amounts [1]. The most common way to utilize woody waste part from forest exploitation is forest woodchip production, but coniferous needles usually falls down and stays in forest, where it become nutrition for next trees. This makes coniferous needles from forestry residues a completely unexploited forest resource.

Coniferous needles have been studied mostly in association with the value of biologically active components in their chemical composition [3, 4]. Nowadays extract production from coniferous greenery (small branches with needles) is the only industrial way how this resource is used.
Consequently, actually utilized amount of coniferous greenery in Latvia is only approximately 50 ton per year [5]. During the last year several studies have assessed possible uses of coniferous greenery from fogging residues as heat insulation material [6, 7]. Historically coniferous greenery has been used for vitamin-meal production, which was used as high quality animal feed [8]. But it was outrivaled by combined feed. As a result production of coniferous greenery vitamin-meals has stopped.

The above proves that there are several ways how to utilize coniferous greenery residues from logging in sustainable way. But it is still not known how much of this resource is available in Latvia and is it enough to be used for other product manufacturing. Also it is not known if the resource will be sufficient for this purpose in the future. Previously, authors of this article had researched the amount of coniferous wood waste in the Baltic States [9]. In that research the approximate amount of coniferous greenery from logging in Baltic States has been determined to be approximately 700 thousand $\mathrm{m}^{3}$ per year. Also Latvia State Forestry research institute "Silava" had made research in which they determined that 0.8 million ton of coniferous greenery are left in forests after logging each year [10]. Unfortunately these studies do not answer the question how the accessible amount of coniferous greenery from logging in Latvia could change depending on the development of forestry. Therefore this research has aims to determine the 
potential of coniferous greenery from logging residues using dynamic approach, which would allow making forecasts of the tendencies for this resource accessibility in the future. To reach this aim, system dynamic (SD) modelling method has been used. SD was developed by Jay Forrester in 1950's [11]. Since then SD has been applied to a diverse set of problems to solve them by simulating their complex dynamic systems. It has to be noted, that the aim of SD modeling is to present the trend of dynamic behavior of the real system, not to give projection of exact values [12]. Thus, the focus is on the relationships rather than on the precision of simulated parametric values.

As far as we know, models that would allow to assess forest resources depending on the development of forestry, also including accessible coniferous greenery have not been developed previously, Therefore, in this research we developed system dynamics model that will be useful instrument for determination of the amount of coniferous greenery

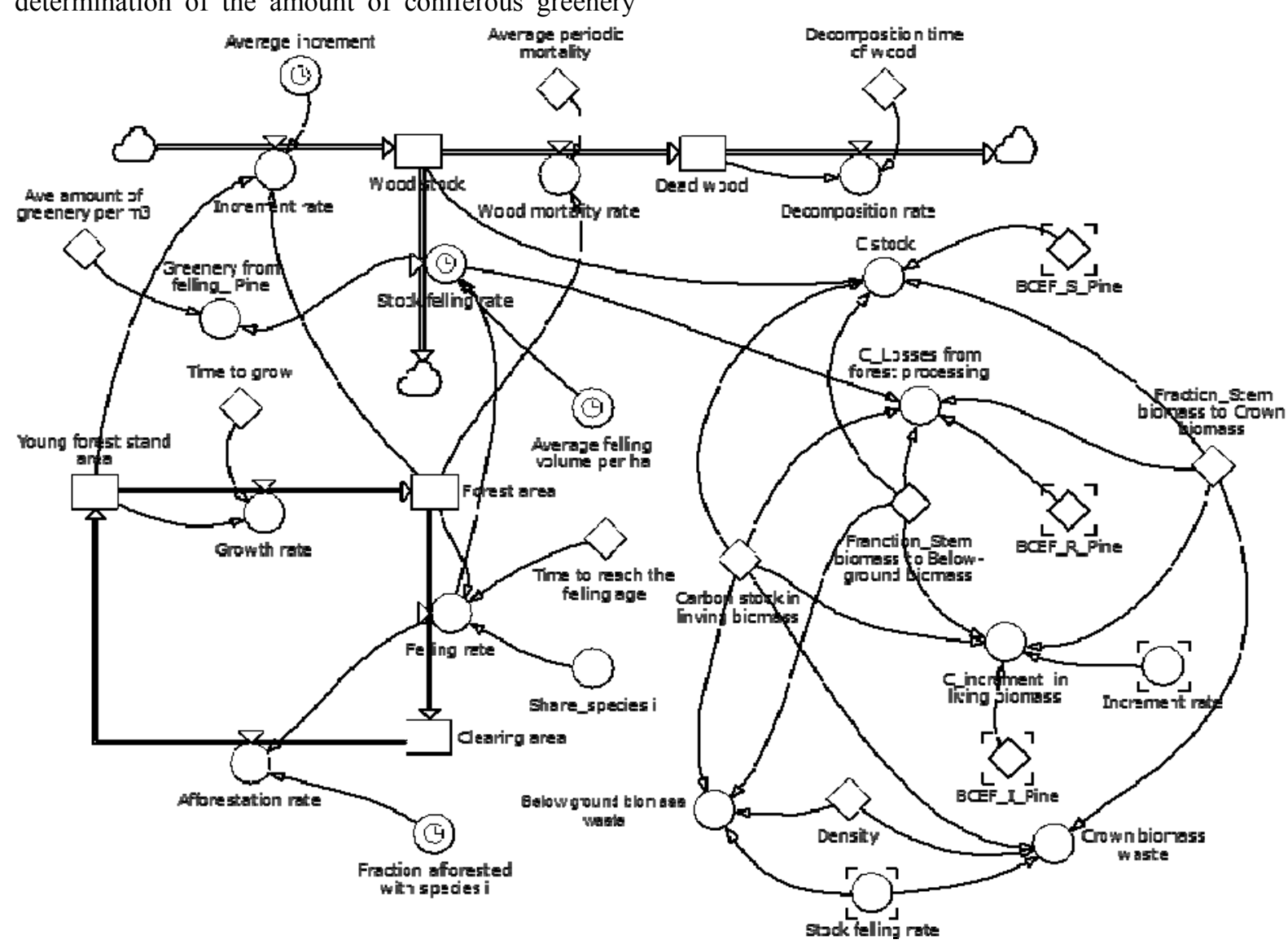

Fig. 1. Stock-and-flow diagram of the coniferous greenery from logging residues

The existing and future amount of accessible coniferous greenery depends on these tendencies. Determination of the amount of accessible coniferous greenery is based on coniferous logging volume and existing coniferous wood stock. It is influenced by average periodic gross increment, average periodic residues from logging forecasting and would help to evaluate possibilities of industrial utilization of this resource. System dynamics model developed in this study is based on historical and theoretical data about coniferous trees (pine and spruce) in Latvia, but it is also possible to adapt it to be used in other countries.

\section{MATERIALS AND METHODS}

In our study, Powersim Studio 8 software was used to develop the system dynamic model. Historical data about existing wood supplies, recovery of forest area, changes in tree species proportions and logging volumes were obtained from Latvian State Forest Service (LSFS) statistical database [13]. The amount of accessible coniferous greenery was simulated for the time period from 2005 till 2070.

SD model (see Fig. 1) was used to simulate the tendencies of logging and recovery of coniferous trees. 
species (spruce and pine), because they have a different management tendency and different amount of greenery.

Tendencies from historical data separately for state and other forests (private and local government) were used to forecast logging tendencies. One of the factors influencing forest logging is a price of wood, exponential function for logging volume in dependence on historical wood prices for each of wood specie has been included in the SD model.

Forest felling in the main felling, depending on the dominant tree species and forest regeneration, is determined by the laws and regulations of the Republic of Latvia (LR) [18]. In Latvia in the main felling it is permitted to cut pine trees with age more than 110 years and spruce trees older than 80 years. Average time to make forest regeneration after logging is 7 years. All these factors influencing forest life cycle are included as part of this SD model

Also in the SD model technological losses in logging time has been considered (see Fig. 2). Model was developed based on the coniferous logging volume in main felling, therefore technological losses are assumed to be $30 \%$ of the amount [19]. In other felling types logging volume is not as big [13] and consequently there are less logging residues. Consequentially, it would be more technically and economically feasible to obtain logging residues in big amount only from the main felling.

In LR the existing regulations and standards for sustainable forestry certification (PEFC - Program for the Endorsement of Forest Certification [20], and FSC - Forest Stewardship Council [21]) do not determine what quantity of logging residues in felling should be left in order to ensure the development of necessary quantity of organic substances. FSC Standard establishes that in forest management logging residues should be decreased [21]. Based on it, the base scenario of the SD model has extra coefficients which would regulate the quantity of logging residues left in felling left. It was assumed that technological losses from felling are sufficient for new forest development.

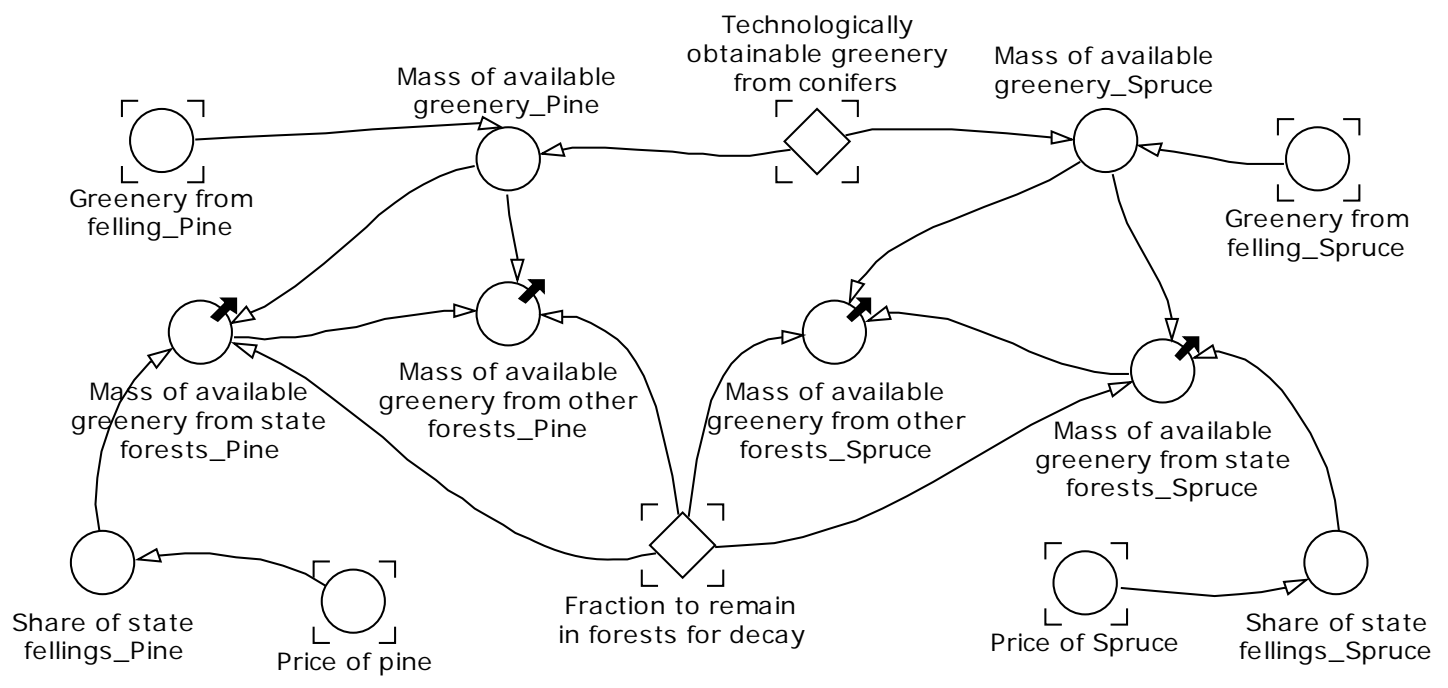

Fig. 2. Stock-and-flow diagram of the technologically obtainable amount of greenery from conifers

As mentioned above, technologically available volumes of coniferous greenery can be sustainably used for multiple products, for example, needle extract and feed production. Recent studies $[6,7]$ have proved that coniferous greenery can be successfully used for thermal insulations material production. With a help of the SD model it is possible to evaluate how much thermal insulation material we could possibly produce from technologically accessible amount of coniferous greenery (see Fig. 3).

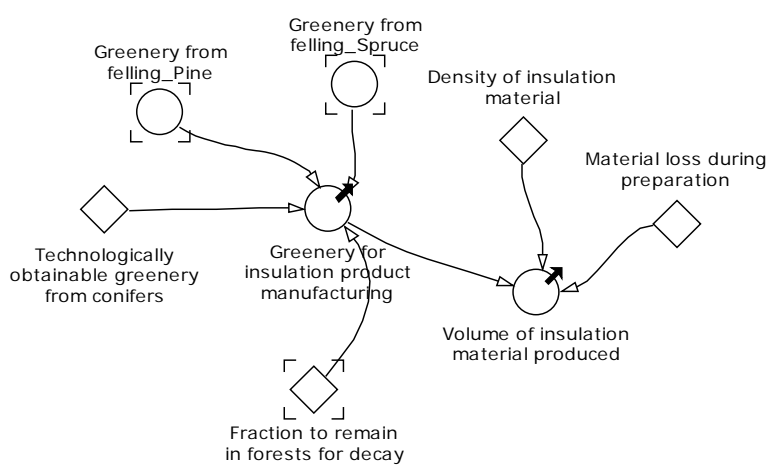

Fig. 3. Stock-and-flow diagram of the greenery for insulation product manufacturing 
In order to determine the dynamics of conifer greenery potential, 5 scenarios were developed and analyzed. In the base scenario technologically accessible amount of pine and spruce is represented. It is the amount that can be obtained each year from logging residues in main felling based on historical data and tendency. Five other situations were modeled based on the results of the base scenario.

In scenario I describes situation when only $50 \%$ of estimated technologically accessible coniferous greenery from logging residues are used for manufacturing. .The rest would stay in forest. In this case more biomass would be left for nutrition in forests. This can be regulated, introducing changes in normative acts that would be establish the amount of greenery that must be left in forest (50\% in this case) in order to practice sustainable forest management and logging.

Scenario II reflects changes in the amount of coniferous greenery in case of $20 \%$ increase of coniferous tree planting. This scenario is assessed because new outlet market for coniferous greenery will increase demand for this recourse. Up till now the price of coniferous wood has been between the highest in comparison with other species of wood. Additional profit obtained selling forestry residues may contribute to increase of coniferous share in new woods. However it must be taken into account that results of such tendency can be detected only after considerable time delay, because coniferous trees have the greatest felling age.

Scenario III reflects similar situation, however in this case it was assumed that, due to increasing demand, felling volumes would increase by $20 \%$.

Scenario IV combines two previous scenarios (scenario II and III) and evaluates the tendency in case if both the felling and planting of trees would increase by $20 \%$.

\section{RESULTS AND DISCUSSION}

According to historical data 233 thousand tons of coniferous greenery was technologically accessible in 2014, from that approximately 112 thousand tons of pine greenery and 121 thousand tons of spruce greenery. Taking into account that from $1 \mathrm{~m}^{3}$ of pine bole wood we can obtain $50 \%$ more greenery than from spruce, the total amount of greenery obtained from pine and spruce trees are almost the same, because pine is felled by $50 \%$ less than spruce [13].

The results of SD model base scenario (see Fig. 4.) shows that, according to current trends, accessible amount of forest greenery from forests belonging to the state, has tendency to decrease.

This is the case with both pine and spruce greenery. Even though historically the situation has been totally opposite, the majority of coniferous greenery was produced in state forests. This can be explained, with the reduction in the amount of forests in felling age, due to intensive felling in state forest that could be observed in the past.

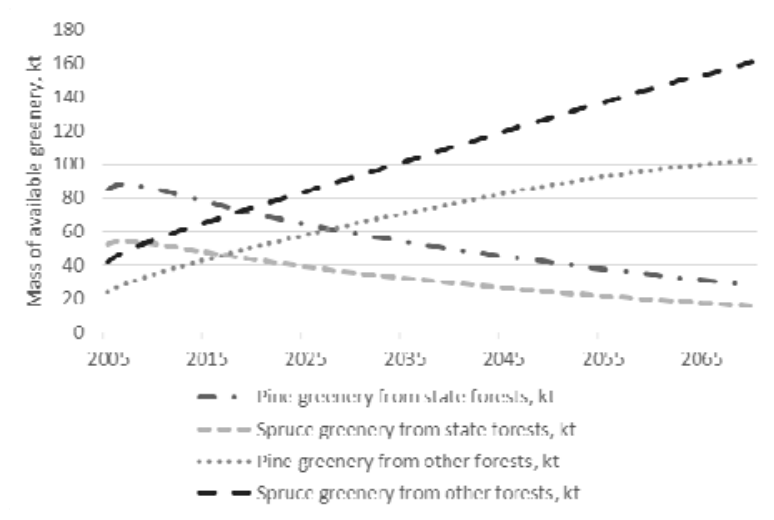

Fig. 4. Mass of available greenery in Latvia from coniferous logging residues in base scenario by the ownership and conifer species

Different situation can be observed in case of private forests. Felling volumes in forests belonging to private owners has tendency to increase.

In practice it would be easier to organize procurement of coniferous greenery for industrial uses in great amounts from single or few big forest owners.

In the best case it would be "Latvian State Forests" (LSF), as they own half of all Latvian forest areas. However base scenario model proves that in the future LSF will not have enough resources for logging to produce the same amount of forest residues as before. Therefore, extraction of coniferous greenery resource in great amounts depends on the cooperativeness of private forest owners and their interest in collection and trading of this resource. Modeled baseline scenario clearly shows that there are different amount of greenery available from different coniferous species, in main fallings of state forests as well as those of private owners.

It is possible to obtain more spruce greenery from LSF felling, and more pine greenery in fellings of other owners.

This is significant in cases if greenery from specific coniferous species is necessary for production of some product. As it was mentioned before developed SD model is also used to determine approximate amounts of insulation material, which can be produced from available coniferous greenery.

If all technologically accessible amounts of greenery from currently ongoing felling would be used to produce heat insulation material with average density of $242 \mathrm{~kg} / \mathrm{m}^{3}$ [6] approximately 485 thousand $\mathrm{m}^{3}$ of environmentally friendly heat insulation material can be produced in year 2015 (taking into account that average moisture content in greenery is $50 \%)$.

Evaluating all developed scenarios (see Fig. 5), it can be seen that the highest increase in coniferous 
greenery mass can be obtained in case of scenario 4 , when felling and planting volumes are increased by 20 $\%$. The results of scenario 3 , in which only felling volume is increased, are also close to this level. This result is obtained because the effect of increase in planting volume does not show pronounced results as early as in 55 years modeling time.

The same can be observed in relation with scenario II, which very gradually increases the amount of accessible greenery. We can conclude that increase in coniferous greenery planting would increase the amount of accessible greenery only after more significant period of time. Therefore increase of raw material availability for new product cannot be based on this strategy.

Least coniferous greenery would be available, in case of strict sustainable forestry regulations were set in place that would prohibit removal of more than 50 $\%$ of technologically accessible amount of forest residues from felling (scenario I and V). However in reality this regulation would be hard to enforce and control, it would provide conditions for sustainable development of industry without serious harm to forest biotopes and their development.

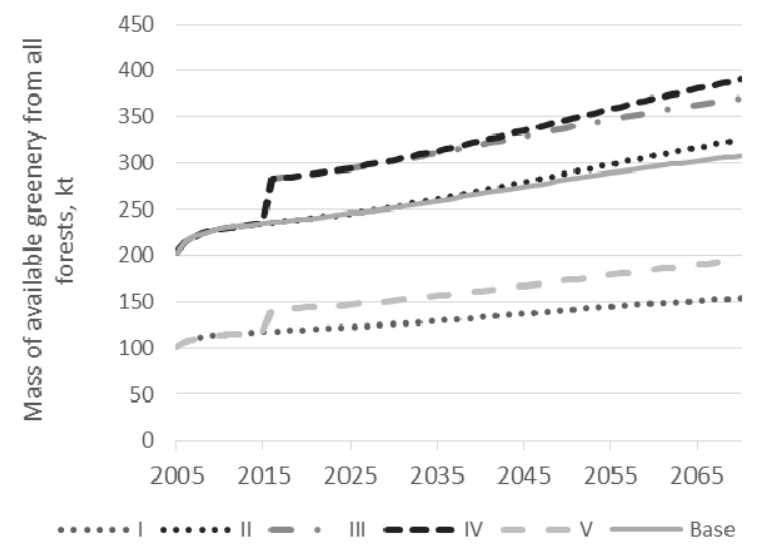

Fig. 5. Results of the effects of various scenarios on available coniferous greenery mass dynamics, 2005-2070

Opinion of authors of this article is that the best and most likely to take place is development similar to scenario 5 .The increase of the demand for coniferous greenery should lead to result in increase in supply. In order to meet the demand felling volumes will increase. Felling volumes are constricted by the amount of coniferous trees in felling age and planting of coniferous trees. $50 \%$ extraction volume from technologically accessible coniferous greenery may not be set in legislation, as a constriction factor in order to ensure sustainable development, however, this amount quantitatively may be that which can be realistically obtained from forest owners and forestry workers. Therefore, when planning production of new products from coniferous greenery and assessing the availability of raw resources, maximal volume to be considered is 117 thousand tons per year (based on the results of scenario $\mathrm{V}$ in 2015 that is obtained from historical data), in future (year 2070) this number will likely be approximately 195 thousand tons. In all scenarios technologically accessible amount of coniferous greenery shows tendency to increase in comparison with year 2015 .

\section{CONCLUSIONS}

Few studies have focused on accessible amount s of coniferous greenery and none so far shows their possible development and how these amounts are affected by different factors. System Dynamic model developed in this study shows dynamic future development tendencies of the technologically accessible amount assessed raw material and allows to forecast tendencies for the availability of this material in the future.

From base scenario we can conclude that coniferous greenery can be obtained from forestry residues in significant amount and this amount is sufficient to be used as raw material for production of new products. As one example of such product we would like to mention thermal insulation material. In this case maximal amount of insulation material produced from coniferous greenery would be 485 thousand $\mathrm{m}^{3}$. Tendencies show that coniferous greenery in the future will be available from private forests in larger amounts than from state forests. Currently pine and spruce greenery can be technologically accessed in similar amounts, however slight tendency towards decrease of the amounts of spruce greenery were observed.

Simulated scenarios indicate that increase in planting of coniferous trees will take effect only after longer time period, which is not considered in this study. By contrast, increase in felling notably increases accessible amounts of coniferous greenery. Legislative acts related to increase in felling volumes and the limited amount of forest resources, which are slow to regenerate, must be taken into account. Implementation of sustainable forestry principles and sequential harvesting of only part of technologically accessible amount of coniferous forestry residues would reduce available amount of raw material, however it would ensure wholesome development of forest biotopes. Using only $50 \%$ of technologically available coniferous greenery would currently allow accessing 117 thousand tons of raw materials yearly, forecasts for year 2070 shows that in would be possible to obtain approximately 195 thousand tons of coniferous greenery under the same conditions. Accordingly, even implementing sustainable forestry principles it is possible to obtain coniferous greenery in amounts that are sufficient to be used as raw material for industrial production. 


\section{ACKNOWLEDGEMENTS}

The work has been supported by the National Research Program "Energy efficient and low-carbon solutions for a secure, sustainable and climate variability reducing energy supply (LATENERGI)".

\section{REFERENCES}

[1] European Union Strategy "Europe 2020: A European strategy for smart, sustainable and inclusive growth," Brussel, 2010.03.03

[2] European Commission strategy. "Innovating for Sustainable Growth: A Bioeconomy for Europe" 13.02.2012.

[3] O. Polis, A. Korica, M. Daugavietis. Bioloǵiski aktīvo savienojumu saglabāšanās egles zalena uzglabāšanas procesā. Mežzinātne 19(52), 2009. [in Latvian]

[4] Daberte I., Barene I., Rubens J., Daugavietis M. Producing and determination of qualitative indices of ordinary pine needles thick extract. European Journal of Pharmaceutical Sciences, Vol. 32, 2007, pp. S32-S33

[5] "Permit for Category B polluting activity", Oct. 14, 2010 [Online]. http://www.vpvb.gov.lv/lv/piesarnojums/a-bAvailable: atlaujas/?ur=vecventa\&id ur=\&search ur submit $=\mathrm{Mekl} \% \mathrm{C} 4$ $\% 93 \mathrm{t}+\mathrm{p} \% \mathrm{C} 4 \% 93 \mathrm{c}+\mathrm{uz} \% \mathrm{C} 5 \% 86 \% \mathrm{C} 4 \% \overline{9} 3$ muma. [Accessed: Jan. 15, 2015].

[6] Muizniece I., Blumberga D., Ansone A. The use of coniferous greenery for heat insulation material production. Energy Procedia, 2015 (in press)

[7] Muizniece I., Lauka D., Blumberga D. Thermal Conductivity of Freely Patterned Pine and Spruce Needles. Energy Procedia, 2015 (in press)

[8] Siliņš Z. "Mežs - Latvijas nacionālā bagātība", Jelgava, 2002, pp. 248 [in Latvian]

[9] Muizniece I., Blumberga D. Analysis of Coniferous Wood Waste in Baltic States. Energy Procedia, 2015 (in press)

[10] Daugavietis M., Polis O., Korica A. M. "Meža nekoksnes produktu izmantošanas tehnologiju ekonomiskais un ekologiskais novērtējums daudzfunkciju mežsaimniecībā," Project report, 2008. [in Latvian]

[11] Forrester J.W. Industrial dynamics: a major breakthrough for decision makers. Harvard Business Review, 36, 1958, pp. 3766.

[12] Sterman J.D. Business dynamics: Systems thinking and modeling for a complex world. Irwin McGraw-Hill, Boston, 2000, $1008 \mathrm{pp}$

[13] State Forest Service statistics, 2005-2014. [Online]. Available: http://www.vmd.gov.lv/valsts-meza-dienests/statiskaslapas/publikacijas-un-statistika?nid=1047\#jump. [Accessed: Jan. 16, 2015].

[14] Lazdiņš, Donis, Strūve. "Latvijas meža apsaimniekošanas radītās ogḷskābās gāzes $\left(\mathrm{CO}_{2}\right)$ piesaistes un siltumnīcefekta gāzu (SEG) emisiju references līmeņa aprēķina modeḷa izstrāde," Project report, 2012. [in Latvian]

[15] "Land use, land use change and forestry sector in Latvia," Jul. 30, 2012. [Online]. Available: https://sites.google.com/site/lvlulucf/activity/nir-19902011/Meza\%20apsaimniekosana\%20\%28FMRL\%202012073 $0 \% 29$. ods? attredirects $=0 \& \mathrm{~d}=1$. [Accessed: Feb. 10, 2015].

[16] Daugavietis M., Polis O., Korica A., Seleznovs J. Scotch pine - a natural raw material for high-quality biologically active substances. Proceedings of the Latvia University of Agriculture, 2012.

[17] Stibe U., "Tree crown elements of quantitative indicators logging old-age spruce forest," $\mathrm{PhD}$. thesis, Latvia University of Agriculture, Jelgava, Latvia, 1976.

[18] Parliament of the Republic of Latvia "The Law on Forests," Latvijas Vēstnesis, 98/99 (2009/2010), 16.03.2000., "Ziņotājs", 8, 20.04.2000. [in Latvian]

[19] Adamovičs A., Dubrovskis V., Plūme I., Jansons Ā., Lazdina D., Lazdiņš A. "Biomasas izmantošanas ilgtspējības kritēriju pielietošana un pasākumu izstrāde," Project report, 2009. [in Latvian]

[20] PEFC Council in Latvia "PEFC Mežu apsaimniekošanas sertifikācijas standarts Latvijai," 2010. [in Latvian]

[21] FSC Association in Latvia "Latvian Forest Certification Council. National FSC Forest Stewardship (Management) Standard for Latvia," 2012 